\title{
Productivity and Resistance of Parental Forms and Hybrid of Sugar Beet Which are Tolerant to Rhizomania Disease
}

\author{
Uchkunov.I $^{1}$., S.Raykov ${ }^{1}$, V. Uchkunov ${ }^{2}$ K. Tanova ${ }^{1 *}$, A. Mehmed ${ }^{2}$ \\ ${ }^{1}$ Konstantin Preslavsky University of Shumen- Shumen \\ ${ }^{2}$ Agricultural Institute of Shumen - Shumen \\ k_tanova@abv.bg
}

\begin{abstract}
The selected varieties and hybrids of sugar beet tolerant to the viral Rhizomania disease / Beet necrotic yellow virus / is one of the innovative fields in the selection of sugar beet. The aim of the present research is to track the economic properties of the new sugar beet hybrids tested under conditions of absence of the viral disease. It is found that among the tests new hybrids outweigh the group standard by $6.7 \%$ in yield of white sugar. Hybrids tolerant to the disease have a higher resistance to fungal diseases cercospora / Cercospora betikola /and mildew /Erysiphe communis. It has been found that the decay of roots in the tolerant to Rhizomania hybrids had proved to be lower (52\%) than that of the standard.
\end{abstract}

Keywords: sugar beet, selection, resistance, tolerance, Rhizomania, fungal diseases.

\section{INTRODUCTION}

Nowadays about 90 million ha of sugar beet are grown. Currently in the world are over 90 million acres of sugar beets. The major producers are Ukraine, France and the United States who annually grow 5-8 million ha.

The highest consumption of sugar in the world is in Austria, Great Britain, Ireland, Russia, Canada and others. This is about $40 \mathrm{~kg}$ per capita. With the least consumption are Japan, Turkey, Denmark (about 23-24 kg). Bulgaria occupies a prestigious place in the top ten worldwide with $35 \mathrm{~kg}$ of sugar consumed per capita.

The role of crop variety is very precise and explicitly formulated. This is a means of production which, under certain soil and climatic conditions and suitable technology ensures particular yields. Sugar beet is relatively flexible crop, but despite it in the southern latitudes of the temperate zone it is often attacked by fungal diseases and conditions in the northern regions favor the boltind. These features, as well as the specific soil and climatic conditions almost every country that cultivates sugar beet has organized its own breeding and seed production of highly productive varieties and technology for their cultivation.

The selected varieties and hybrids of sugar beet tolerant to the viral Rhizomania disease / Beet necrotic yellow virus / is one of the innovative aspects in the selection of sugar beet.

\subsection{Literature Review}

At the current stage of beet growing the most serious damage is caused by viral viral Rhizomania disease.(Uchkounov and Uchkounova, 2003) Our observations show that the yield of root crops declines considerably. The technological qualities of the raw material are deteriorated sharply. It is not a rare case when the whole harvest is compromised. The main characteristic of Rhizomania lies in the proliferation of roots. In 1995 there have been infected more than 400 thousand ha with the virus of Rhizomania in Europe (Knappe 1997). In Bulgaria the infected with the virus of Rhizomania areas are about 15 thousand ha and they are mainly in the areas of sugar factories Gorna Oryahovitsa, Russe and Kameno - Burgas.

During the vegetation in the main root of the beet a number of alterations are observed. In general they can testify about the presence of the virus. In cross-section transverse necrotic circles are easily noticed. When the disease appears later the root crop is usually well-developed and secondary roots are observed only in the top part or in separate branches of the main root. 
Tanova (2003) proves that the fungus Polymyxa betae carries the virus BNYVV, causing disease of Rhizomania in sugar beet (Harveson and Rush 1994). This fungus is described by Keskin. In our country the disease was discovered in the region in 1983 in Radnevo, Haskovo, initially symptomatically and subsequently the disease was diagnosed in France by the method of ELISA (Uchkunov , 2008)

Fighting viral disease of Rhizomania is very difficult because once entering the soil it is practically almost impossible for it to be cleansed. Direct anti-virus control is impossible, and the fight against vector of Polymyxa beate does not give satisfactory results.

For now, the most reliable way to overcome the negative effects of the disease is the development of varieties of tolerant sugar beet which in infected rhizomes with Rhizomania soils guarantee a normal yield with relatively good technological qualities of the raw material. (Zelyazkov and Uchkunov,2005)

Currently the created genetico-selective material as well as the skills of virologists and breeders give confidence that overcoming the phenomenon of Rhizomania is possible (Desprez and Desprez , 1998 Kikindonov et al.,2010). The first Bulgarian variety called Radnevo tolerant to Rhizomania was recognized in 1990 and it was introduced into cultivation in 1991 -1992 (Uchkunov, 2008).

Purpose of the research

The aim of this study is to track the agricultural features and resistance to fungal diseases of the newly created hybrids of sugar beet tolerant to the viral disease of Rhizomania.

\section{Material AND Methods}

Studies were conducted in the Agricultural Institute of Shumen - scientific research field of "Crop" and Konstantin Preslavsky University of Shumen during the period between 2012-2013.

In topic developing the topic the following selection materials from these breeding gene pool of Agricultural Institute, which is included in the group for the conservation of genetic resources in the EU (Uchkunov et al., 2015)

Standard varieties for Bulgaria - Peshtera and Dieks and diploids and single-fruit male sterile lines № № 6634, 201, 222, 5524, 5332 and 5140 as well as and their single-fruit triploid monogerm hybrids.

Tetraploid multiple pollinators - 5319R, 4499R and 5314R viral disease of Rhizomania.

In tracking the productive and economic qualities of selection materials is based on field experience.

The experience is set according to two-place-grid method - with 36 variants in four repetitions and size of the test lot $10.8 \mathrm{~m} 2$.

\section{RESUlTS AND DISCUSSION}

The results received from the research on the productivity of the newly created hybrids

and parent varieties tolerant to the viral disease of Rhizomania are presented in Table 1.

It has been found that according to the yield of root crops per ha, the highest yield had been observed in hybrids with the participation of the multiple pollinator, tolerant to Rhizomania, 4499, where the yield reaches $3985 \mathrm{~kg} / \mathrm{da}$. It has been proved to have higher yield in three hybrids.

In terms of sugar content in root crops the average for all hybrids reaches $15.62 \%$. The overall highest sugar content is found in hybrids featuring genotype of 4499 as a father component (15.95\%). It is noteworthy to mention that there is a high percentage of sugar content of multiple pollinators as highest is that of $5319-16.84 \%$.

Essential in the production of sugar molasses are the forming factors. From the study it is apparent that both the standard and the resulting hybrids average content of soluble ash is below $0.400 \%$, which in practice is considered that the raw material is of good quality. The data shows that $73 \%$ of the hybrids exhibit relatively low soluble ash compared with the standard.

The yield of white sugar is the most important technological indicator. The average for the standard yield of white sugar reaches $13.02 \%$. The highest yield is observed with the hybrid combination MS201x5314 where excess over the standard is $112 \%$, the difference is very well supplied. 
Productivity and Resistance of Parental Forms and Hybrids of Sugar Beet which are Tolerant to Rhizomania Disease

The yield of white sugar per ha, as resultant value indicates that newly created hybrids generally excel the group standard. As promising for selection are the hybrids MS222h5319 and MS201h4499 where the excess is with $17.6 \%$ and the difference is demonstrated for GD $0.1 \%$. The results show that on average the new test hybrids tolerant to the viral disease of Rhizomania are superior the group standard with $6.75 \%$.

Table1. Productivity of hybrids and parental components of sugar beet tolerant to the

\begin{tabular}{|c|c|c|c|c|c|}
\hline \multirow{2}{*}{ Origin } & Root yield & Sugar content & Soluble ashes & Output & Whitesugar yield \\
\hline & $\mathrm{kg} / \mathrm{da}$ & $\%$ & $\%$ & $\%$ & $\mathrm{~kg} / \mathrm{da}$ \\
\hline Standart & 3850 & 15,16 & 325 & 13,02 & 502 \\
\hline MC5140X5319 & 99,8 & 106,5 & 89,9 & 106,7 & 106,5 \\
\hline MC5332X5319 & 103,7 & 98,0 & 103,0 & 99,1 & 102,8 \\
\hline MC5524X5319 & 99,3 & 96,3 & 101,9 & 95,9 & 95,2 \\
\hline MC222X5319 & 108,4 & 108,3 & 89,2 & 108,5 & 117,6 \\
\hline MC6634X5319 & 107,0 & 106,2 & 90,3 & 107,1 & 114,5 \\
\hline MC201X5319 & 98,1 & 104,6 & 91,4 & 105,2 & 103,1 \\
\hline MC5140X5314 & 98,9 & 102,4 & 96,4 & 103,3 & 101,1 \\
\hline MC5332X5314 & 93,7 & 99,5 & 98,8 & 99,6 & 93,2 \\
\hline MC5524X5314 & 99,2 & 97,8 & 100,6 & 97,7 & 96,9 \\
\hline MC222X5314 & 98,3 & 94,9 & 108,0 & 93,7 & 92,0 \\
\hline MC6634X5314 & 103,2 & 104,9 & 93,0 & 106,5 & 109,7 \\
\hline MC201X5314 & 115,8 & 110,0 & 96,4 & 112,0 & 129,5 \\
\hline MC5140X4499 & 109,4 & 102,8 & 92,8 & 103,8 & 113,6 \\
\hline MC5332X4499 & 93,0 & 107,7 & 89,2 & 109,0 & 101,2 \\
\hline MC5524X4499 & 109,4 & 102,4 & 101,1 & 102,9 & 112,5 \\
\hline MC222X4499 & 105,8 & 105,0 & 96,7 & 106,0 & 112,1 \\
\hline MC6634X4499 & 95,2 & 105,7 & 91,9 & 107,6 & 102,3 \\
\hline MC201X4499 & 108,1 & 102,7 & 99,8 & 108,9 & 117,6 \\
\hline MM4X5319 & 108,7 & 111,1 & 99,0 & 113,0 & 122,6 \\
\hline MM4X5314 & 106,0 & 101,9 & 94,4 & 102,9 & 108,9 \\
\hline MM4X4499 & 100,2 & 103,1 & 94,0 & 103,3 & 103,4 \\
\hline GD 5\% & 8,6 & 7,7 & 14,7 & 8,6 & 9,1 \\
\hline GD $1 \%$ & 9,9 & 10,2 & 19,5 & 12,7 & 10,8 \\
\hline GD $0,1 \%$ & 11,7 & 13,2 & 25,1 & 16,3 & 12,2 \\
\hline $\mathrm{P} \%$ & 4,66 & 3,09 & 6,09 & 3,79 & 11,89 \\
\hline
\end{tabular}

With regard to the attack of the economically important fungal disease cercospora is presented in Fig.

The average values for the standard for attack by the disease reported in rating are 3.99. The tested hybrids with respect to this disease show a value of 4.34 rating, which is an excess of $8.8 \%$ compared to the standard. The highest resistance is found in pollinator $9661 \mathrm{R}$, where the value is 4.51 rating.
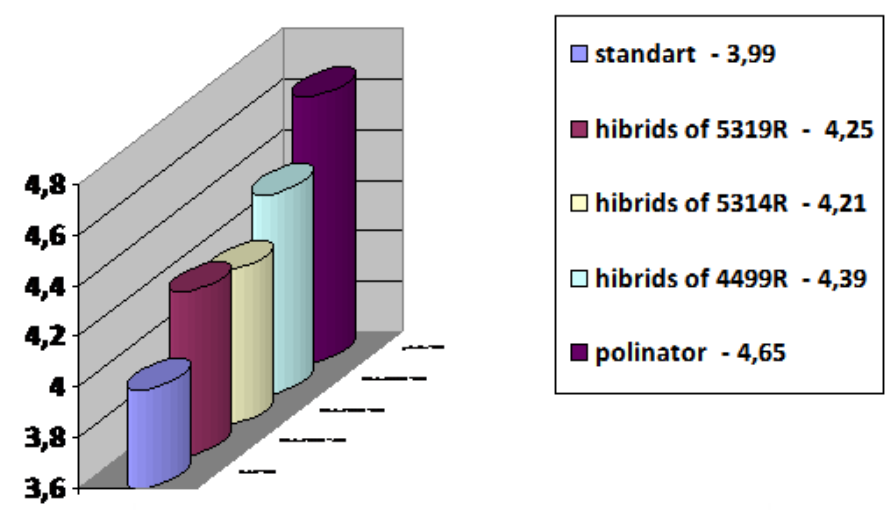

Fig1. Attack of cercepera

Here the excess in relation to the standard is $6.1 \%$ 
From the conducted research work one can draw the preliminary conclusion that the hybrids tolerant to Rhizomania in the absence of the disease show higher resistance to cercospora.

The climatic conditions in the years of testing under natural conditions gave the opportunity to evaluate the rate of rotting root crops. These results are shown in fig 2.

The percentage of rotting roots in the group standard for the period of the research is $12.3 \%$. In reviewing the data for the investigational rotting roots in the tested hybrids and parental forms it was found that the decay in the roots of the rootstocks of the tolerant to Rhizomania hybrids was proved lower than that of the standard

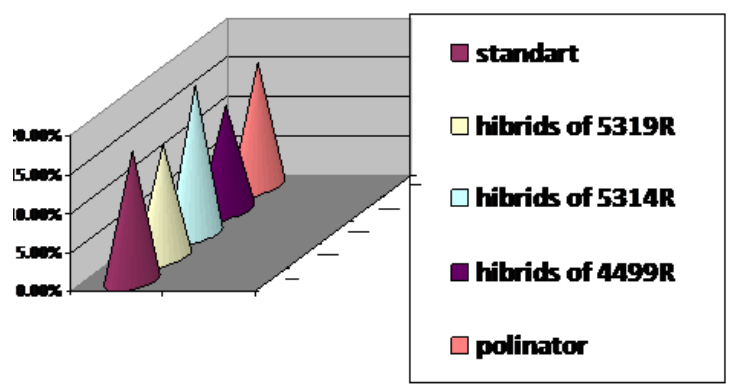

Fig2. Rotten roots $\%$

It was found that the average of the tested new hybrids tested exceeded the extraction of white sugar the group standard by $6.7 \%$.

\section{Conclusions}

The hybrids tolerant to Rhizomania in the absence of the disease show higher resistance to cercospora.

It was found that the decay of root crops in the tolerant to Rhizomania hybrids of is proved lower than that of the standard.

\section{ACKNOWLEDGEMENT}

This study was carried out under a project funded by the University of Shumen.

\section{REFERENCES}

[1] Desprez M., . Desprez B., 1998. Selection de la betterave sucriere pour la resistance an cercospora et la tolerance aux virus de la jgnnise. 42 congres dhiver, conenses des communications.

[2] Harveson M. R., Rush C. M., 1994. Evaluation of fumigation and rhizomania tolerant cultivars for control of a root disease complex of sugar beet. Plant Diseases, 78, 12,1197- 1202.

[3] Harveson M. R., Rush C. M., 1994. Movement of BNYVV - infested Polymyxa betae from an inoculated point source. J. Phytopatogy, 10, 186-193.

[4] Kikindonov,G., Uchkunov,I., Tz.,Kikindonov and K. Uchkunova.2010. Assessment of the Male Sterility, Monogermity and Triple-Cross Hybrids of Sugar Beet. Green Plant Breeding Technologies International Conference,February 2-5, 2010, Vienna. Austria: p.79

[5] Knapp E., 1997. Hybridzuchtung vbei Zuckenruben. Zucker, 25, N14, s. 459 - 463.

[6] Tanova K., 2003 Study on Rhizoctonia solani Uuhn, a cause for decay of root sugar beet during the vegetation period. Sofia. Abstract thesis.

[7] Uchkounov,I., K. Uchkounova, (2003). Sitation et tendences de la selection betteraviere en Bulgarie France I. I. R.B. info, 10, 13 - 15.

[8] Uchkunov I., 2008. Sugar beet. Shumen: Union Express, ISBN 978-954-9454-36-9

[9] Uchkunov, I., Raykov, S., V. Uchkunov. 2015 Selection-and-agrotechnical aspects of beetroot and salad beet - monography. FABER, ISBN: 978-619-00-0288-

[10] Zelyazkov, D., I. Uchkunov, (2005). Testing of parental forms and hybrids of sugar beet Rhizomania tolerant. Scientific works of NCAS vol. 3, pp. 339-342. 
AUTHORS'BIOGRAPHY

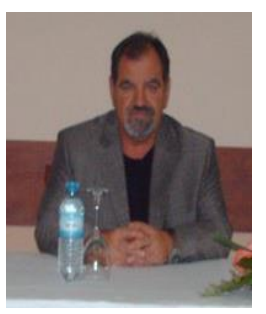

Iliya Uchkunov - Bulgaria, Professor, Doctor of Agricultural Sciences works in Shumen University branch Dobrich, department "Plant and Plant Protection" from 2012 - Head of the Department. Research interests - selection of beet, stevia, immuno selection and immunity, horticulture, vegetable production. Author of 16 varieties of sugar, Semi, and fodder beet salad and 1 stevia variety.

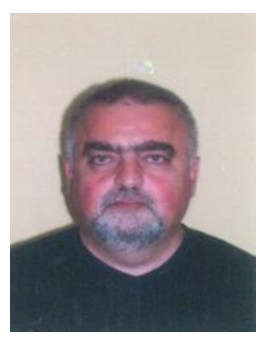

Svilen Raikov- Bulgaria, Professor Works in Konstantin Preslavsky University, Shumen, Bulgaria; Faculty of Natural Sciences Department of Agrarians Sciences and Plant Protection. FIELDS OF INTEREST: Herbology, general agriculture, organic farming and ecology.

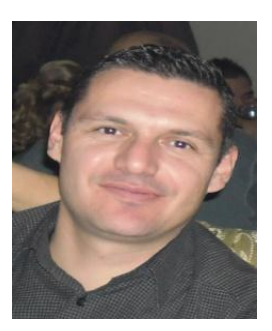

Veselin Iliev Uchkunov- Bulgaria, Master Agronomist in Plant Protection in the Agricultural Institute - Shumen, Department Selection and Plant Proection. FIELDS OF INTEREST - selection and plant protection of stevia.

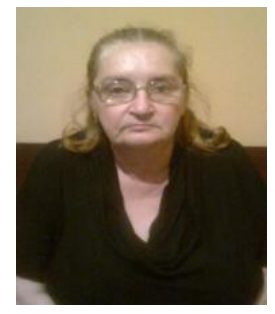

Krasimira Trifonova Tanova- Bulgaria, Associate Professor Works in Konstantin Preslavsky University, Shumen, Bulgaria; Faculty of Natural Sciences Department of Agrarian Sciences and Plant Protection. FIELDS OF INTEREST: Phytopathology, immunity, integrated plant protection, quarantine, microbiology and ecology.

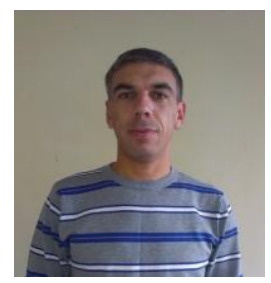

Achmed Mehmed - Bulgaria, Master Agronomist in Plant Protection in the Agricultural Institute - Shumen, Department Plant breeding . FIELDS OF INTEREST - selection and immunity of stevia. 